\title{
Knowledge and attitudes in the rural Western Cape towards pesticides in water sources
}

\author{
Mohamed A Dalvie ${ }^{1 *}$, Leslie London ${ }^{1}$, Simphiwe Mbuli ${ }^{2}$ and Eugene Cairncross ${ }^{3}$ \\ ${ }^{1}$ Occupational and Environmental Health Research Unit, Department of Public Health and Family Medicine, School \\ of Health Sciences, University of Cape Town, Anzio Road, Observatory 7925, Cape Town, South Africa \\ ${ }^{2}$ Department of Health Sciences, Peninsula Technikon, Private Bag 1906, Bellville 7535, South Africa \\ ${ }^{3}$ Department of Engineering, Peninsula Technikon
}

\begin{abstract}
There is a need for pesticide water monitoring in South Africa and for community awareness with regard to chemical contamination of rural water sources.

The results of two descriptive studies in the rural Western Cape are reported. One assessed water usage and the knowledge, attitudes and practices in relation to water of farm residents (229 participants from 60 farms) in the Slanghoek Valley, Hex River Valley and Grabouw (KAP) and the other (monitoring capacity survey), investigated water usage and the capacities of rural communities (63 farm residents from 16 farms in three local authorities and 8 environmental health officers (EHOs) from 7 local authorities) to conduct monitoring of pesticides in rural water sources.

Most farm residents in both surveys identified protected sources such as groundwater from springs and boreholes (30 to $60 \%)$, and water from mountain dams (40 to 65\%), as the most important sources for drinking and other domestic purposes. Many $(>40 \%$ ), however, also reported farm dams. For use in the field (both drinking and other), potentially contaminated sources (river, subsurface drains, dams) were more frequently reported. Forty-eight percent of participants also reported swimming in farm dams. Other water sources reported included municipal, rain and canal water. In the monitoring capacity survey, $27 \%$ reported using untapped water. About a third of respondents in the KAP survey reported living within $10 \mathrm{~m}$ of the nearest site of spraying and many used pesticides at home for pest control (41\%) and in the garden (33\%). While almost all participants $(>90 \%)$ in both surveys were aware that pesticides and polluted water could be harmful, many did not identify health effects $(20 \%)$ especially chronic effects $(91 \%)$ or reported no training $(37 \%)$ in health effects. In all 7 districts surveyed in the monitoring capacity survey, water sources on farms are tested by EHOs. Only $3(37 \%)$ respondents felt that there were enough persons conducting water monitoring in their area. Only 1 respondent reported that pesticides were monitored, and only in request to a complaint. Three state laboratories, that did not have the analytical capacity to conduct routine pesticide water monitoring at low $(<0.1 \mathrm{mg} / \ell)$ detection limits, were identified as conducting water analyses.

The study found that farm residents in the Western Cape are potentially exposed to pesticides through various environmental routes including water. This emphasises the need to monitor water for pesticides in the Western Cape, but in order to do this, human and laboratory resources and capacities to conduct routine pesticide water monitoring need to be increased.
\end{abstract}

Keywords: pesticide knowledge, water, pollution, monitoring capacity

\section{Introduction}

South African water pollution control legislation has changed substantially in recent years. Following a consultative process involving the publication of a White Paper on a National Water Policy for South Africa (Department of Water Affairs and Forestry, 1997), and a Draft White Paper on Integrated Pollution and Waste Management for South Africa (Department of Environmental Affairs and Tourism, 1998), Parliament enacted the National Water Act in 1998 (Department of Water Affairs and Forestry, 1998). One of the principal changes contained in the Act is the move toward management of water resources on a catchment basis, based on "demand" rather than supply, and emphasising greater conservation of water resources through measures such as an appropriate pricing system. The Act also emphasises public participation and provides for greater community involvement in water management

\footnotetext{
* To whom all correspondence should be addressed.

푱 +2721 4066610; fax: +2721 4066163;

e-mail: aqiel@cormack.uct.ac.za

Received 10 July 2003; accepted in revised form 30 October 2003.
}

structures. Additionally, the Department of Water Affairs and Forestry's (DWAF) White Paper recognises the lack of access of millions of South Africans to a safe water supply.

However, despite the importance of the agrochemical industry in the South African economy (National Department of Agriculture, 1998; Torres et al., 2000) and high levels of pesticide usage in the country (London and Myers, 1995a; b) relatively little monitoring of rural water sources in SA has taken place with regard to pesticide pollution (London et al., 2000). Thus, in addition to a probable lack of knowledge and capacity, opportunities for rural farming communities to participate in water catchment management are limited by the lack of data on pesticide pollution. Nonetheless, studies have increasingly begun to report on pesticide pollution arising from farming activities in SA. Weaver (1993) found atrazine present in water entering irrigation systems in the Northern Cape, resulting from runoff from maize farming. London et al. (2000) found consistent pesticide pollution of surface-and groundwater including drinking water in three rural Western Cape agricultural districts in 1996-1997. The polluted drinking water was identified mostly in dams and boreholes used by rural communities, but also in two major dams contributing to municipal 


\begin{tabular}{|c|c|c|c|c|c|}
\hline \multicolumn{6}{|c|}{$\begin{array}{c}\text { TABLE } 1 \\
\text { Sampling and participation in the two surveys }\end{array}$} \\
\hline $\begin{array}{l}\text { Dates and } \\
\text { site }\end{array}$ & Sample type & $\begin{array}{l}\text { Population } \\
\text { (N) }\end{array}$ & $\begin{array}{l}\text { Sample } \\
\text { (n) }\end{array}$ & $\begin{array}{c}\text { Participating } \\
\text { farms/ } \\
\text { local } \\
\text { authority }\end{array}$ & $\begin{array}{l}\text { Participating } \\
\text { subjects }\end{array}$ \\
\hline \multicolumn{6}{|c|}{ Survey in Slanghoek, Hex River and Grabouw } \\
\hline $\begin{array}{l}\text { June 1997: } \\
\text { Slanghoek } \\
\text { Valley }\end{array}$ & $\begin{array}{l}\text { All farms in } \\
\text { Slanghoek } \\
\text { Valley }\end{array}$ & 18 & 18 & 12 & $\begin{array}{l}7 \text { farm owners } \\
3 \text { managers } \\
12 \text { spray operators } \\
9 \text { farm workers } \\
9 \text { non-farm workers }\end{array}$ \\
\hline \multirow[t]{2}{*}{$\begin{array}{l}\text { October 1999: } \\
\text { Grabouw/ } \\
\text { Vyeboom }\end{array}$} & $\begin{array}{l}\text { Farms on which } \\
\text { water sampling } \\
\text { was conducted }\end{array}$ & 5 & 5 & 2 & $\begin{array}{l}2 \text { managers } \\
2 \text { spray operators } \\
2 \text { farm workers } \\
2 \text { non-farm workers }\end{array}$ \\
\hline & Random sample & 145 & 40 & 29 & $\begin{array}{l}7 \text { owners } \\
23 \text { managers } \\
29 \text { spray operators } \\
28 \text { farm workers } \\
25 \text { non-farm workers }\end{array}$ \\
\hline \multirow[t]{2}{*}{$\begin{array}{l}\text { October 1999: } \\
\text { Hex River } \\
\text { Valley }\end{array}$} & $\begin{array}{l}\text { Farms on which } \\
\text { water sampling } \\
\text { was conducted }\end{array}$ & 6 & 6 & 4 & $\begin{array}{l}2 \text { managers } \\
3 \text { spray operators } \\
3 \text { farm workers } \\
3 \text { non-farm workers }\end{array}$ \\
\hline & Random sample & 147 & 40 & 13 & $\begin{array}{l}5 \text { owners } \\
10 \text { managers } \\
14 \text { spray operators } \\
16 \text { farm workers } \\
13 \text { non-farm workers }\end{array}$ \\
\hline TOTAL & & 321 & 109 & 60 & 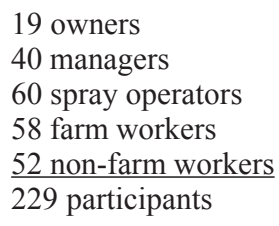 \\
\hline \multicolumn{6}{|c|}{ Study of capacities within rural Western Cape to monitor water } \\
\hline $\begin{array}{l}\text { September } \\
2001\end{array}$ & Random sample & 93 LA's & $\begin{array}{l}12 \text { LA's } \\
(60 \text { staff } \\
\text { members, } \\
5 \text { from } \\
\text { each LA })\end{array}$ & 7 LA's & 8 EHO's \\
\hline $\begin{array}{l}\text { October } \\
2001\end{array}$ & $\begin{array}{l}\text { Convenient } \\
\text { sample, access } \\
\text { arranged by } \\
\text { EHO }\end{array}$ & & $\begin{array}{c}36 \text { farms } \\
(3 \text { farms in } \\
\text { each LA }), \\
180 \text { farm } \\
\text { residents } \\
(5 \text { from } \\
\text { each farm })\end{array}$ & $\begin{array}{l}16 \text { farms } \\
\text { from } \\
3 \text { LA's }\end{array}$ & $\begin{array}{l}7 \text { owners } \\
28 \text { managers } \\
6 \text { spray operators } \\
20 \text { farm workers } \\
63 \text { participants }\end{array}$ \\
\hline
\end{tabular}

supplies. Recently, azinphosmethyl and endosulfan resulting from orchard runoff, were also detected in the Lourens River (Schultz, 2001). In a study of indigenous fish species in South African rivers (CSIR, 1996), which included the Berg River in the Western Cape, the maximum whole fish load of organochlorines reached high-risk levels in worst-case scenarios (fish eaten daily all year round).

These studies emphasise the need for pesticide water monitoring in South Africa, and point to the importance of community awareness with regard to chemical contamination of rural water sources.

This paper reports the results of two surveys conducted within an investigation of potential pesticide pollution of rural water sources (London et al., 2000; London et al., 2002). One study was conducted to meet the objective of assessing the practices of farm residents in relation to water as part of a major study investigating pesticide water pollution in three agricultural areas in the Western Cape, and the second investigated the capacities of rural communities to conduct monitoring of pesticides in rural water sources. The latter was part of a project aimed at developing environmental monitoring methods for pesticides in rural waters, to support implementation by local communities (London et al., 2002).

\section{Methods}

Both studies were descriptive cross-sectional in design and conducted in the rural Western Cape. Study one (farm resident knowledge, attitudes and practices (KAP)) was conducted on farms in the Slanghoek Valley, Hex River Valley and Grabouw, three intensive agricultural areas in the Western Cape. The latter two areas were chosen as sites for intensive sampling for pesticide pollution (Dalvie et al., 2003) while the survey in the Slanghoek Valley was conducted as an 


\begin{tabular}{|c|c|c|c|c|c|c|}
\hline \multicolumn{7}{|c|}{$\begin{array}{c}\text { TABLE } 2 \\
\text { Demographic and water monitoring data of districts surveyed in the Western Cape, } 2001\end{array}$} \\
\hline \multirow[t]{2}{*}{ Districts } & \multirow[t]{2}{*}{ Towns } & \multirow[t]{2}{*}{ Population } & \multirow{2}{*}{$\begin{array}{l}\text { Persons } \\
\text { testing } \\
\text { water }(n)\end{array}$} & \multirow{2}{*}{$\begin{array}{l}\text { Water sources } \\
\text { monitored }\end{array}$} & \multicolumn{2}{|c|}{ Number of times per annum } \\
\hline & & & & & Regular & Pesticides \\
\hline $\begin{array}{l}\text { Boland District } \\
\text { Municipality }\end{array}$ & $\begin{array}{l}\text { Robertson, Bonnievale, } \\
\text { Ashton }\end{array}$ & 21000 & EHO (3) & $\begin{array}{l}\text { Municipal sources, } \\
\text { canals dams }\end{array}$ & Variable & On request \\
\hline $\begin{array}{l}\text { Boland District } \\
\text { Municipality }\end{array}$ & Stellenbosch & 31000 & EHO (2) & $\begin{array}{l}\text { Boreholes, dams, } \\
\text { rivers }\end{array}$ & 52 & On request \\
\hline Overberg & Caledon & 60000 & EHO (6) & $\begin{array}{l}\text { Boreholes, dams, } \\
\text { rivers }\end{array}$ & 43 & On request \\
\hline West Coast & $\begin{array}{l}\text { Moreesberg, Malmes- } \\
\text { bury, Reibeeck West, } \\
\text { Darling, Porterville }\end{array}$ & 22000 & EHO (5) & $\begin{array}{l}\text { Boreholes, canals, } \\
\text { roof water }\end{array}$ & 52 & On request \\
\hline Oostenberg & Brakenfell, Kuilsrivier & 79000 & EHO (4) & Boreholes, dams & 4 & On request \\
\hline Drakenstein & $\begin{array}{l}\text { Saron, Wellington, } \\
\text { Paarl, Gouda }\end{array}$ & 150000 & EHO (14) & Boreholes, dams & 75 & On request \\
\hline Breederivier & $\begin{array}{l}\text { Rawsonville, Touws- } \\
\text { rivier, De Doorns, } \\
\text { Worcestor }\end{array}$ & 110000 & EHO (NR) & Piped water & 43 & On request \\
\hline Witzenberg & Ceres & 31000 & EHO (2) & Household water & $\begin{array}{l}\text { Bacteria: } 12 \\
\text { pH: } 365\end{array}$ & When suspect* \\
\hline
\end{tabular}

exploratory study early in the project to field-test the questionnaire. Because data in the Slanghoek Valley survey were collected using the same questionnaire and trained interviewers as in the main study and because of the high participation rate amongst farms (Table 1) and the fact that the majority of questions in the questionnaire were answered, the results are combined. All farms in the Slanghoek area were surveyed $(n=18)$. For the other two study areas, two sampling strategies were used. One arm selected a random sample of 40 farms from each study area based on a listing obtained from the producers' associations ( $\mathrm{n}=147$ in Hex River and $n=145$ in Grabouw/Vyeboom) in those areas. In addition to the random sample, the farms on which water sampling took place ( $n=5$ in Grabouw and $n=6$ in Hex River Valley) were also included in the survey. Sampling and participation in the survey is described in Table 1.

Access to farms was arranged through the local producers' organisations. For each farm, interviews were sought with the owner or manager, one pesticide applicator, one farm worker (nonapplicator), and one farm resident not working on the farm. Liaison with the farm owner or manager meant that the workers participating in the study were not randomly selected. Interviews explored water usage (sources at home and in the field for drinking and nondrinking purposes), contamination of water sources, drift, domestic use of pesticides or containers and knowledge of, and training in pesticide safety. Interviews were conducted in Afrikaans and administered by the project co-ordinator and students from the
Peninsula Technikon (Pentech) Department of Health Sciences. Surveys took place in 1997 and 1999.

For the second study (monitoring capacity survey), a survey of farm workers and local authority management, was planned. A sample of 12 Western Cape local authorities including 8 municipalities and 4 district councils was randomly selected from a total population of 93 obtained from the Western Cape Local Government Organisation. The sample included the municipalities of Ashton, Bonnievale, Bredasdorp, Caledon, Grabouw, Klawer, Oostenberg, and Overberg and the district councils of Plettenberg Bay, Central Karoo, West Coast and Bree River. For every local authority it was planned to select 5 officials and 5 farm personnel each from 3 farms for participation in the survey (Table 1). Separate questionnaires were developed for local authority officials and farm workers by environmental health students from Pentech supervised by 2 senior researchers from Pentech and one from UCT. The questionnaire for local authorities included questions on district demographics, current water monitoring on farms in the district and knowledge of pesticides and training received, while the questionnaire for farm personnel included questions on water usage on the farm, water monitoring on farms and knowledge of pesticides and their dangers.

The survey was conducted during September and October 2001 by 9 trained environmental health students from Pentech supervised by 2 senior researchers from Pentech and one from UCT. 


\begin{tabular}{|c|c|c|c|c|c|}
\hline \multicolumn{6}{|c|}{$\begin{array}{c}\text { TABLE } 3 \\
\text { Water sources by purpose and by area, as percentage of farms in the Hex River, } \\
\text { Slanghoek and Grabouw areas, } 1997 \text { and } 1999\end{array}$} \\
\hline \multirow[t]{2}{*}{ Purpose } & \multirow[t]{2}{*}{ Source reported* } & Slanghoek & $\begin{array}{l}\text { Grabouw/ } \\
\text { Vyeboom }\end{array}$ & Hex river & All farms \\
\hline & & $n=12$ & $n=31$ & $n=17$ & $n=60$ \\
\hline Drinking & $\begin{array}{l}\text { Mountain dam } \\
\text { Spring/borehole } \\
\text { Rainwater entrapment } \\
\text { Farm dam } \\
\text { River }\end{array}$ & $\begin{array}{c}50 \% \\
58 \% \\
8 \% \\
8 \% \\
8 \%\end{array}$ & $\begin{array}{c}74 \% \\
55 \% \\
1 \% \\
71 \% \$ \\
10 \%\end{array}$ & $\begin{array}{c}65 \% \\
76 \% \\
0 \% \\
23.5 \% \\
0 \%\end{array}$ & $\begin{array}{c}67 \% \\
62 \% \\
3 \% \\
45 \% \$ \\
7 \%\end{array}$ \\
\hline $\begin{array}{l}\text { Domestic use } \\
\text { other than } \\
\text { drinking }\end{array}$ & $\begin{array}{l}\text { Storage dam } \\
\text { Spring/borehole } \\
\text { Rainwater entrapment } \\
\text { Farm dam } \\
\text { River }\end{array}$ & $\begin{array}{c}50 \% \\
58 \% \\
8 \% \\
8 \% \\
8 \%\end{array}$ & $\begin{array}{c}74 \% \\
55 \% \\
1 \% \\
71 \% \$ \\
10 \%\end{array}$ & $\begin{array}{c}65 \% \\
76 \% \\
0 \% \\
23.5 \% \\
0 \%\end{array}$ & $\begin{array}{c}67 \% \\
67 \% \\
3 \% \\
45 \% \$ \\
7 \%\end{array}$ \\
\hline Field ablutions & $\begin{array}{l}\text { Storage dam } \\
\text { Spring/borehole } \\
\text { Rainwater entrapment } \\
\text { Farm dam } \\
\text { River } \\
\text { Sub-surface drain }\end{array}$ & $\begin{array}{c}25 \% \\
58 \% \\
0 \% \\
8 \% \\
50 \% \\
17 \%\end{array}$ & $\begin{array}{c}90 \% \\
35 \% \\
3 \% \\
80 \% \$ \\
10 \% \\
0 \%\end{array}$ & $\begin{array}{c}71 \% \\
77 \% \\
0 \% \\
35 \% \\
0 \% \\
6 \%\end{array}$ & $\begin{array}{c}72 \% \\
52 \% \\
2 \% \\
53 \% \$ \\
15 \% \\
5 \%\end{array}$ \\
\hline Recreation & Swimming in farm dam & $66.7 \%$ & $29 \%$ & $29 \%$ & $48 \%$ \\
\hline 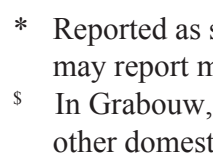 & $\begin{array}{l}\text { upplied for the farm. Perc } \\
\text { ore than one source. } \\
\text { many respondents reporte } \\
\text { c purposes because many }\end{array}$ & $\begin{array}{l}\text { entages are no } \\
\text { f farm dams a } \\
\text { farms in this }\end{array}$ & $\begin{array}{l}\text { t mutually e: } \\
\text { s the water s } \\
\text { area store wa }\end{array}$ & $\begin{array}{l}\text { lusive as re } \\
\text { urce for drit } \\
\text { in these fo }\end{array}$ & $\begin{array}{l}\text { pondents } \\
\text { ing and } \\
\mathrm{m} \text { dams }\end{array}$ \\
\hline
\end{tabular}

\section{Results}

\section{Study participation}

Farm resident $K A P$

Two hundred and twenty nine subjects (from 60 farms) of which $8 \%$ were farm owners, $18 \%$ managers, $26 \%$ spray operators, $25 \%$ non-spraying farm workers who were not operating spray equipment and $23 \%$ other farm residents, participated in the survey. The response rate was $55 \%$ for farms and $42 \%$ for participants.

\section{Monitoring capacity survey}

Sixty-three subjects including 7 owners (11\%), 28 managers (44\%), 6 sprayers $(10 \%)$ and 22 (35\%) other workers participated in the second survey of Western Cape districts. The subjects were drawn from 16 participating farms from the Boland, West Coast and Overberg areas. The response rate was therefore $44 \%$ for farms and $35 \%$ for farm workers. The farms were near 7 towns, which included Bonnievale, Grabouw, Malmesbury, Paardeberg, Riebeeck Kasteel, Riebeeck Rivier and Robertson. Although the second project aimed to survey various local officials involved in water monitoring, only 8 EHOs from 7 districts could be interviewed (Table 1). Local authority staff other than health personnel were reluctant to participate, perhaps because they viewed water quality as a health matter. As a result, no town clerks, executive officers, or engineers were surveyed as intended. The districts surveyed included 21 towns with a total population of 503000 estimated by the participating EHOs (Table 2).

\section{Water sources}

Water sources reported for domestic uses

\section{Ethics}

All participants in the study were guaranteed of confidentiality, and participation in the field surveys took place only after respondents had the study fully explained to them, and were able to give informed consent. Care was taken by the researchers to ensure that no farm workers suffered any adverse consequence as a result of their participation in the study. Co-operation of key stakeholders in the study areas was crucial to the progress of the projects. (London et al., 2000). Feedback of results of the first survey was given in a workshop of stakeholders held at Nietvoorbij Institute (Stellenbosch) during 2001. in the KAP survey are summarised in Table 3.

Groundwater from springs and boreholes, and water from relatively pristine mountain sources were identified as the most important source for drinking water for the farming community in the Western Cape. Farm dams are, however, also important sources. Many of these farm dams drain surface water from rivers, either alone or mixed with mountain sources or groundwater. Relatively few farms are dependent solely on surface water for drinking. Sources of water for domestic purposes closely mirror those for drinking. For use in the field (both drinking and other), potentially contaminated sources (river, sub-surface drains, dams) are used 
more frequently, particularly in the Slanghoek area. In the Grabouw area, water from the Groenland Water Scheme is stored in farm dams for drinking on many farms. Thus, water sources used for drinking on farms appear to be mainly from protected sources, while nondrinking usage and usage while in the field appears to make use of more surface water albeit at low frequencies.

The results were similar for the 2001 survey which found that on 16 farms in the Boland, West Coast and Overberg municipalities, the water sources reported were mountain dam (44\%); dam or river $(44 \%)$; boreholes $(25 \%)$; rain $(19 \%)$; municipal supply (19\%); canal (13\%); spring (6\%); and irrigation $(6 \%)$.

In the second survey, $68 \%$ $(n=60)$ of farm residents reported having taps in the house, while $27 \%$ reported using untapped water.

\section{Potential risk of pesticide pollution of water sources}

About a third of respondents in the KAP survey reported living within $10 \mathrm{~m}$ of the nearest site of spraying (Table 4) and this percentage was higher in Slanghoek $(58 \%)$. Seven (11\%) respondents reported that pesticides from pesticide spray had within the preceding 6 months drifted into their homes (Table 5), and similarly the percentage was highest in Slanghoek (18\%).

Other opportunities presented for multiple sources of exposure appear to be high (Table 5). A sizeable number of respondents including both farmers and farm workers, used pesticides, either for domestic pest control or for home gardening, and about half of the farm workers reported obtaining these pesticides from the farm store. However, reuse of pesticide containers was low, reported by only $9 \%$ of farm residents, and this was always reported as being for the purpose of serving as a garbage bin.

In the KAP survey, awareness of the hazards of pesticides was reported as high, with farm workers scoring slightly higher than farm owners or managers (Table 5). While all respondents $(n=59)$ in the survey of monitoring capacity knew that using polluted water
TABLE 5

Risk activities, knowledge and attitude toward pesticides on farms reported by farm residents in the Slanghoek, Hex River Valley and Grabouw areas, 1997 and 1999

\begin{tabular}{|c|c|c|c|c|}
\hline \multirow[t]{2}{*}{ Risk } & \multicolumn{4}{|c|}{ Respondents } \\
\hline & $\begin{array}{l}\text { Slanghoek } \\
(n=40)\end{array}$ & $\begin{array}{l}\text { Grabouwl } \\
\text { Vyeboom } \\
(n=120)\end{array}$ & $\begin{array}{l}\text { Hex River } \\
(\mathrm{n}=69)\end{array}$ & $\begin{array}{l}\text { All respondents } \\
(n=229)\end{array}$ \\
\hline $\begin{array}{l}\text { Reported spray } \\
\text { drifting into home } \\
\text { All subjects } \\
\text { Farmers } \\
\text { Farm workers }\end{array}$ & $\begin{array}{l}18 \%(\mathrm{n}=31) \\
20 \%(\mathrm{n}=5) \\
23 \%(\mathrm{n}=26)\end{array}$ & $\begin{array}{l}13 \%(\mathrm{n}=119) \\
14.3 \%(\mathrm{n}=7) \\
12.5 \%(\mathrm{n}=112)\end{array}$ & $\begin{array}{l}4 \%(n=69) \\
0 \%(n=5) \\
6.4 \%(n=64)\end{array}$ & $\begin{array}{l}11.9 \%(\mathrm{n}=218) \\
11.8 \%(\mathrm{n}=17) \\
11.9(\mathrm{n}=201)\end{array}$ \\
\hline $\begin{array}{l}\text { Use of pesticides at } \\
\text { home for pest control } \\
\text { All subjects } \\
\text { Farmers } \\
\text { Farm workers }\end{array}$ & $\begin{array}{l}30 \%(\mathrm{n}=40) \\
57.1 \%(\mathrm{n}=7) \\
24.0(\mathrm{n}=33)\end{array}$ & $\begin{array}{l}48 \%(\mathrm{n}=118) \\
57.1 \% 1(\mathrm{n}=7) \\
47.3 \%(\mathrm{n}=111)\end{array}$ & $\begin{array}{l}36 \%(n=69) \\
0 \%(n=5) \\
39 \%(n=64)\end{array}$ & $\begin{array}{l}41 \%(n=227) \\
42 \%(n=19) \\
41 \%(n=209)\end{array}$ \\
\hline $\begin{array}{l}\text { Use of pesticides for } \\
\text { home garden } \\
\text { All subjects } \\
\text { Farmers } \\
\text { Farm workers }\end{array}$ & $\begin{array}{l}13 \%(\mathrm{n}=40) \\
42.9 \%(\mathrm{n}=7) \\
6.1 \%(\mathrm{n}=33)\end{array}$ & $\begin{array}{l}42 \%(\mathrm{n}=118) \\
57.1 \%(\mathrm{n}=7) \\
40.5 \%(\mathrm{n}=111)\end{array}$ & $\begin{array}{l}29 \%(\mathrm{n}=69) \\
40 \%(\mathrm{n}=5) \\
28.1 \%(\mathrm{n}=64)\end{array}$ & $\begin{array}{l}32.6 \%(\mathrm{n}=227) \\
47 \%(\mathrm{n}=19) \\
31 \%(\mathrm{n}=218)\end{array}$ \\
\hline $\begin{array}{l}\text { Of those using pesticides, } \\
\text { what proportion obtain } \\
\text { pesticide from farm } \\
\text { All subjects } \\
\text { Farmers } \\
\text { Farm workers }\end{array}$ & $\begin{array}{l}33 \%(\mathrm{n}=16) \\
80 \%(\mathrm{n}=5) \\
36.4 \%(\mathrm{n}=11)\end{array}$ & $\begin{array}{l}58 \%(\mathrm{n}=76) \\
20 \%(\mathrm{n}=5) \\
60.6 \%(\mathrm{n}=71)\end{array}$ & $\begin{array}{l}51 \%(\mathrm{n}=35) \\
50 \%(\mathrm{n}=2) \\
51.2 \%(\mathrm{n}=33)\end{array}$ & $\begin{array}{l}53 \%(\mathrm{n}=127) \\
16.7 \%(\mathrm{n}=12) \\
55.7 \%(\mathrm{n}=115)\end{array}$ \\
\hline $\begin{array}{l}\text { Use of pesticides at } \\
\text { home in past } 6 \text { months } \\
\text { All subjects } \\
\text { Farmers } \\
\text { Farm workers }\end{array}$ & $\begin{array}{l}92.3 \%(\mathrm{n}=13) \\
100 \%(\mathrm{n}=5) \\
87.5 \%(\mathrm{n}=8)\end{array}$ & $\begin{array}{l}62 \%(\mathrm{n}=64) \\
60 \%(\mathrm{n}=5) \\
52.5 \%(\mathrm{n}=59)\end{array}$ & $\begin{array}{l}50 \%(\mathrm{n}=32) \\
0 \%(\mathrm{n}=2) \\
56.7 \%(\mathrm{n}=30)\end{array}$ & $\begin{array}{l}54.6 \%(\mathrm{n}=109) \\
66.7 \%(\mathrm{n}=12) \\
56.7 \%(\mathrm{n}=97)\end{array}$ \\
\hline $\begin{array}{l}\text { Reuse of pesticide } \\
\text { container at home } \\
\text { All subjects } \\
\text { Farmers } \\
\text { Farm workers }\end{array}$ & $\begin{array}{l}15 \%(\mathrm{n}=39) \\
85.7 \%(\mathrm{n}=7) \\
18.8 \%(\mathrm{n}=32)\end{array}$ & $\begin{array}{l}12 \%(\mathrm{n}=18) \\
42.9 \%(\mathrm{n}=7) \\
9.7 \%(\mathrm{n}=11)\end{array}$ & $\begin{array}{l}0 \%(\mathrm{n}=67) \\
0 \%(\mathrm{n}=5) \\
0 \%(\mathrm{n}=62)\end{array}$ & $\begin{array}{l}9 \%(\mathrm{n}=226) \\
15.8 \%(\mathrm{n}=19) \\
8.2 \%(\mathrm{n}=207\end{array}$ \\
\hline $\begin{array}{l}\text { Knew pesticides were } \\
\text { dangerous to their health } \\
\text { All subjects } \\
\text { Farmers } \\
\text { Farm workers }\end{array}$ & $\begin{array}{l}88 \%(\mathrm{n}=40) \\
70 \%(\mathrm{n}=7) \\
93 \%(\mathrm{n}=33)\end{array}$ & $\begin{array}{l}93 \%(\mathrm{n}=120) \\
84 \%(\mathrm{n}=7) \\
96 \%(\mathrm{n}=113)\end{array}$ & $\begin{array}{l}94 \%(\mathrm{n}=69) \\
94 \%(\mathrm{n}=5) \\
94 \%(\mathrm{n}=64)\end{array}$ & $\begin{array}{l}92 \%(n=229) \\
85 \%(n=19) \\
95 \%(n=210)\end{array}$ \\
\hline
\end{tabular}

could be very harmful, less than $20 \%$ reported that chemicals could pollute water or identified long-term effects such as cancer (Table 6). Twenty per cent ( $\mathrm{n}=56)$ said that they didn't know the effects caused by pesticide-polluted water, and many farm workers (37\%) also said they were not informed or trained with regard to the health effects of pesticides (Table 6). Those reporting that they were informed or trained on the health effects of pesticides, scored 
TABLE 6

Knowledge of pesticide water pollution, health effects and training on farms as a percentage of individuals in rural Western Cape farming districts, 2001

\begin{tabular}{|l|c|c|c|}
\hline Variable & Farmers (n) & $\begin{array}{c}\text { Farm } \\
\text { workers (n) }\end{array}$ & $\begin{array}{c}\text { All partici- } \\
\text { pants(n) }\end{array}$ \\
\hline 1.Knowledge of pesticide pollution & & & \\
$\quad$ Did not know how are pesticides applied & $0 \%(6)$ & $28 \%(53)$ & $25 \%(\mathrm{n}=59)$ \\
Chemicals can pollute water & $50 \%(6)$ & $13 \%(48)$ & $17 \%(\mathrm{n}=54)$ \\
\hline 2.Knowledge of pesticide health effects & & & \\
$\quad$ Polluted water can harm humans & $100 \%(6)$ & $100 \%(53)$ & $100 \%(\mathrm{n}=59)$ \\
Identified chronic effects & $29 \%(7)$ & $6 \%(49)$ & $9 \%(\mathrm{n}=56)$ \\
Did not identify health effects & $14 \%(7)$ & $20 \%(49)$ & $20 \%(\mathrm{n}=56)$ \\
\hline 3.Training on pesticide health effects & $\mathrm{n}=5$ & $\mathrm{n}=35$ & $\mathrm{~N}=40$ \\
A. Not informed or trained about health & $0 \%$ & $37 \%$ & $33 \%$ \\
effects of pesticide & & & \\
Method of training: & & & \\
Farmer's union or co-operative & $20 \%$ & $6 \%$ & $13 \%$ \\
Medical person & $0 \%$ & $9 \%$ & $8 \%$ \\
$\quad$ Pesticide or private company & $80 \%$ & $17 \%$ & $18 \%$ \\
Farm management & & $26 \%$ & $20 \%$ \\
Municipality & $0 \%$ & $3 \%$ & $3 \%$ \\
Brochures & $0 \%$ & $3 \%$ & $3 \%$ \\
Personal studies & $0 \%$ & $6 \%$ & $5 \%$ \\
B. Time since training & $\mathrm{n}=4$ & $\mathrm{n}=16$ & $\mathrm{n}=20$ \\
$<1$ month & $0 \%$ & $6 \%$ & $5 \%$ \\
$<6$ month & $0 \%$ & $31 \%$ & 35 \\
$<1$ year & $25 \%$ & $38 \%$ & 40 \\
C. Follow-up training & $40 \%(5)$ & $28 \%(29)$ & $29 \%(\mathrm{n}=34)$ \\
\hline
\end{tabular}

districts, are summarised in Table 2. In all seven districts surveyed, water sources on farms are tested by environmental health officers (EHOs). The number of EHOs per district varies according to the population in the area, but it is clear that in some areas such as Oostenberg there are relatively few EHOs for the district population. Only $3(37 \%)$ respondents felt that there were enough persons conducting water monitoring in their area.

The water sources being monitored in the areas include municipal sources, canals, dams, boreholes, rivers and roof water. The typical monitoring procedure is the random collection of a grab water sample, which is then sent to a laboratory. The laboratories mentioned were the State Laboratory in Woodstock (SAIMR), the South African Bureau of Standards (SABS), in Pretoria and the CSIR in Stellenbosch. All the respondents mentioned that water was monitored for bacteria and most $(88 \%)$ mentioned that chemicals were monitored only on request. Only 1 respondent reported that pesticides were monitored, and only

TABLE 7

Comparison of knowledge of pesticide water pollution and health effects between respondents reporting training and those reporting no training in the study of rural Western Cape farming districts, 2001

\begin{tabular}{|l|c|c|}
\hline Variable & $\begin{array}{c}\text { Participants } \\
\text { reporting } \\
\text { training }\end{array}$ & $\begin{array}{c}\text { Participants } \\
\text { reporting } \\
\text { no training }\end{array}$ \\
\hline 1. Knowledge of pesticide pollution \\
$\quad$ Did not know how are pesticides applied \\
Chemicals can pollute water & $16 \%(25)$ & $38 \%(13)$ \\
& $26 \%(23)$ & $8 \%(12)$ \\
\hline 2. Knowledge of pesticide health effects & & \\
$\quad$ Identified chronic effects & $16 \%(25)$ & $8 \%(12)$ \\
Did not identify health effects & $8 \%(25)$ & $8 \%(12)$ \\
\hline
\end{tabular}

in response to a complaint

Monitoring was paid for by the local authority, with one respondent indicating that the farm owner paid if he or she requested testing. However, any testing outside of routine sampling (such as pesticides) was seen as the financial responsibility of the person requesting the testing (e.g. the farmer).

With regard to feedback of results one respondent said that there was feedback to the farmer and the province after every analysis, while three said that there was feedback to the farmer on request only.

\section{Farms}

Farm personnel from $8(50 \%)$ of 16 farms reported that water was tested on their farms, including testing for chemicals. However, no respondent mentioned water being tested for higher than those who reported no training (Table 7). Training and information on pesticides differed amongst respondents with only 10 (29\% out of 34$)$ reporting follow-up on training (Table 6$)$.

\section{Capacities for monitoring pesticide water pollution}

\section{Local authorities}

The results of the interviews with rural EHOs on capacities for monitoring pesticides in rural areas in the survey of Western Cape pesticides. Testing was reported as being conducted by the farmer $(n=3)$, the municipality $(n=2)$, private company (1), by the CSIR $(n=2)$, and by the farming co-operative $(n=1)$. Frequency of reported testing varied widely from daily to yearly, depending on what was being tested. Only 2 respondents reported receiving feedback on the results of testing, and they were both managers. Only one farm employee (out of 21) and one manager (out of 12) reported any training in how to test water. Farm employees reported virtually no involvement in water monitoring, especially for pesticides. 


\section{Discussion}

The results of the two surveys suggest that contamination of water sources may be an important route of exposure to pesticides for farm residents in the Western Cape. This is consistent with evidence from a survey of farms conducted in Stellenbosch in 1998 which found that just over $50 \%$ of respondents used borehole water for daily drinking and $20 \%$ used surface water for drinking (Te Water Naude, 2000). Storage of water in farm dams, in particular, is widespread. This is a concern because water monitoring results in rural Western Cape studies (London et al., 2000; Dalvie et al., 2003; Davies, 1997) have consistently found pesticides in farm dams. Although the presence of pesticides in water in these studies coincides mostly with runoff and irrigation events, there was also some correlation with spraying. The proximity of dams to pesticide spraying may therefore be a route of exposure worth attention and control. Water monitoring results in the Hex River, Grabouw and Piketberg (London et al., 2000; Dalvie et al., 2003) also showed that pesticides were detected in groundwater sources such as boreholes, which are the main source of water for drinking or other domestic purposes in both surveys reported in this paper. Notably up to $18 \%$ of farm workers in the KAP survey reported spray drifting into their homes (Table 5), tending to confirm the significance of this mode of exposure. Between 30 and $58 \%$ of farm residents live in very close proximity $(<10 \mathrm{~m})$ to orchards, vineyards or fields subject to pesticide application, increasing opportunities for direct exposure through drift. Use of untapped water for domestic purposes ( $27 \%$ of farm residents) and the use of unprotected sources in the field $(20 \%)$ may also enhance potential exposure to pesticides. Swimming in farm dams (16.8\%) was lower than in the Dopstop survey (45\%) (Te Water Naude, 2000), but may still present an additional source of exposure, albeit of unclear significance. Other environmental sources may be potential exposures to pesticides for farm residents, including use of pesticides at home (of which about a half is obtained from farm sources) and reuse of containers, the latter at low frequency and exclusively as garbage containers. Reuse of containers for water storage did not appear to occur at all. The extent to which environmental exposures contribute to body burden and cause health effects is unclear due to the absence in these studies of comprehensive environmental exposure data and data on biological exposures and health outcomes. Health effects can be acute due to short-term high dose exposure such as poisoning events or chronic due to long-term low dose exposure such as cancers. The former are easier to observe and document than the latter, about which there is uncertainty.

A high percentage of participants in both surveys appeared to be aware that pesticides are harmful with awareness slightly better amongst farm workers than amongst farmers. The positive effects of education reported by some of the employers in the area appear to be borne out by low levels of reuse of containers $(9 \%)$, which augurs well for public health and occupational hygiene measures needed to control pesticide exposure. However, there was a low awareness that pesticides can pollute water (17\%) and little knowledge of the health effects of pesticides $(55 \%)$. There is therefore a need to educate farm residents about the health effects of pesticides, especially with many participants in the study reporting that they were not trained or informed about this. Of the participants who did receive training, more than $40 \%$ did not obtain it from the farm, pesticide company or farming co-operative, thus indicating significant opportunities for involvement in training by employers, employer organisations and trade unions.

Data from the local authorities confirmed the lack of water monitoring for pesticides in rural areas in this part of South Africa. Currently, water is mainly being monitored for bacterial contamination, at frequencies that vary from once monthly to once yearly, but there is no effective pesticide monitoring taking place in the areas surveyed. Given the use of unprotected water sources and the presence of pesticides in rural waters (London et al., 2000; Davies, 1997; Schultz, 2001), it is clear that water monitoring in many areas needs to be increased.

Environmental health officers (EHOs) are currently the public officials responsible for water monitoring in farming areas and they would probably be responsible should systematic water monitoring for pesticides be implemented in future. A previous study (Rother et al., 2002) evaluating the role of the EHOs in promoting pesticide safety in the Western Cape, found that their role is limited as they lack capacity other than conducting inspections, is reactive in that it depends on notification and is not educational. Although most of the EHOs that participated in this study felt that their knowledge of pesticide health effects was good, the previous study on EHOs (Rother et al., 2002) found that their training was theoretical and lacked practical application. For example, they had a limited capacity in providing instructions on pesticide poisonings and pesticide safety issues in general and also had a limited understanding of the circumstances involved in pesticide poisoning. It is also clear that both the number of EHOs and their skills need to be increased to be effective in water monitoring for pesticides.

It would appear from the farm surveys that the financial responsibility for water monitoring on farms currently is seen to rest with the owner or farming co-operative. Though this may be said to reflect the "polluter pays" principle, various tiers of government also have constitutional obligations to ensure an environment not hazardous to health (Glazewsky, 2000). The survey showed that not all farms have the capacity to monitor water, and it is not clear if those that have existing capacity will be able to monitor pesticides. Most farm personnel that participated in the study are not involved in water monitoring and have not received training nor are they informed about the health effects of pesticides in water. Empowering farm personnel to participate in the control of pesticide pollution of rural water sources needs to be integrated in a cocoordinated national and local governmental approach to pesticide monitoring.

Currently there are 4 state laboratories (State Forensic Laboratory, The South African Bureau of Standards, Agricultural Research Council, the CSIR) available to conduct water analysis for pesticides in rural Western Cape areas, with 2 of these situated in Pretoria. These laboratories are not all set up to maintain equipment to perform pesticide water analysis with high sensitivity and low detection limits. Currently, the cost of using these laboratories for routine monitoring is unaffordable. (London et al., 2002). If fullscale monitoring of pesticides in water is implemented, the resources and capacity of the current state laboratories will have to be improved substantially or the number of laboratories will have to be increased in order to handle the sample numbers.

The survey in Western Cape districts also identified that owners or managers of farms receive little feedback of water monitoring results. This is a serious problem which might deter future participation by communities in monitoring activities.

\section{Conclusions and recommendations}

Water usage for domestic purposes on farms occurs mostly from protected sources, but usage from unprotected sources such as farm dams does occur. Farm residents are potentially exposed to pesticides through various environmental routes including water. 
There appears to be regular water monitoring in farming areas, but not for pesticides. Monitoring is conducted by EHOs who reported a good knowledge of the health effects of pesticides, but there is a shortage of staff and skills in many areas. There is at present insufficient analytical capacity in the Western Cape to conduct routine pesticide water analysis. Lack of feedback to owners could be a serious obstacle for future monitoring activities.

The following recommendations are made:

- A national water monitoring programme for pesticides needs to be implemented in South African farming areas and farms. This can be done by intensifying and expanding current water monitoring in rural areas, for example, by collecting water samples weekly from selected groundwater and surface water sites as proposed elsewhere (London et al., 2002). In order to do this, human resources and funding to local authorities for chemical analysis need to be increased, and cost-effective environmental monitoring methods need to be identified. Environmental health officers should be trained in monitoring pesticides and managing a routine surveillance system.

- A manual and guidelines need to be fully developed to inform persons conducting water monitoring on the correct procedures to follow in testing water for pesticide contamination. Local community involvement in participating in, and interpreting results of monitoring, and checking remedial steps to correct water quality, are consistent with current policy directions, and should be encouraged through the development of a user-friendly manual.

- Existing capacity for conducting pesticide analysis should be enhanced.

- Results of any monitoring must be fed back to farmers. A proper management system for handling the data needs to be developed.

- Similarly, farm residents need to be informed that pesticides can pollute water and can affect health, particularly chronic health conditions, which are often delayed in onset, and difficult to link to a harzardous pesticide exposure. Raising awareness could be undertaken by all relevant stakeholders including employers, employer organisations, trade unions, farming co-operatives and pesticide companies. Awarenessraising could be integrated in current health and safety training mandated by occupational health legislation for farm workers in terms of the hazardous chemical substances regulations (London, 1995).

\section{Acknowledgements}

We would like to thank the Water Research Commission and Medical Research Council for their financial support; Brian Delcarme, Shafiek Hassan, and Rashieda Bartlette from Peninsula Technikon for organising the monitoring capacity survey; environmental health students from Peninsula Technikon for conducting both surveys; the Hex River Producers Association, the Elgin Grabouw Vyeboom Villiersdorp Agricultural Association and the Bree River Regional Service Council for arranging access to farms in the KAP survey; and all the environmental health officers, farmers and farm workers who participated in the surveys.

\section{References}

CSIR (1996) Overview of the Pesticide and Heavy Metal Levels Present in the Populations of the Larger Indigenous Fish Species of Selected South African Rivers. Division of Water. Environment and Forestry Technology, CSIR.

DALVIE MA, CAIRNCROSS E, SOLOMON A and LONDON L (2003) Contamination of rural surface and ground water by endosulfan in farming areas of the Western Cape, South Africa. Environmental Health: A Global Access Science Source 2 (1) http://www.ehjournal.net/ content/2/1/1. [electronic journal]

DAVIES H (1997) An Assessment of the Suitability of a Series of Western Cape Farm Dams as Water Bird Habitats. M.Sc. (Conservation Biology) Thesis, Zoology Department, University of Cape Town.

DEPARTMENT OF ENVIRONMENTAL AFFAIRS AND TOURISM (1998) Draft White Paper on Integrated Pollution and Waste Management for South Africa. A policy on Pollution Prevention, Waste Minimization, Impact Control and Remediation. General Notice 1686 of 1998. Government Gazette 19 August 1998398 (19161) Government Printers, Pretoria.

DEPARTMENT OF WATER AFFAIRS AND FORESTRY (DWAF) (1997) South African Water Quality Guidelines. Volumes 1-7. DWAF, Pretoria.

DEPARTMENT OF WATER AFFAIRS AND FORESTRY (1998). $\mathrm{Na}$ tional Water Act. Act 36/1998. DWAF, Pretoria.

GLAZEWSKI J (2000) Pollution of fresh water. Chapter 21 in Environmental Law in South Africa. Butterworths, Durban. 757-780.

LONDON L (1995) Biological Monitoring of workers exposed to organophosphate pesticides: Guidelines for field application. Occupational Health Southern Africa 1 (4) 13-17.

LONDON L, DALVIE MA, CAIRNCROSS E and SOLOMON A (2000) The Quality of Surface and Groundwater in the Rural Western Cape with Regard to Pesticides. WRC Report No. 795/1/00. WRC, Pretoria.

LONDON L and MYERS JE (1995a) Agrichemical usage patterns and workplace exposure in the major farming sectors in the southern region of South Africa. SA J. Sci. 91 515-522.

LONDON L and MYERS JE (1995b) General patterns of agrichemical usage in the Southern Region of South Africa. SA J. Sci. 91 509-514.

LONDON L, DALVIE MA, CAIRNCROSS E and SOLOMON A (2002) Cost-effective Methods for Monitoring Pesticide Pollution in Rural Water Systems: Technologies and Procedures for Field Use in Rural Areas. WRC Report No: 1120/1/02. WRC, Pretoria.

NATIONAL DEPARTMENT OF AGRICULTURE (1998) Agricultural Policy in South Africa. A Discussion Document. Ministry for Agriculture and Land Affairs, Pretoria.

ROTHER HA, PRINSLOO T and LONDON L (2002) Pesticides Health Policy and Practice: A Review of the Role of Environmental Health Officers in South Africa. Presentation to Int. Conf. on Pesticides Exposure and Health. Natcher Centre, Bethesda, Maryland.

SCHULTZ R (2001) Comparison of spraydrift- and runoff-related input of azinphos-methyl and endosulfan from fruit orchards into the Lourens River, South Africa. Chemosphere 45 543-551.

TE WATER NAUDE JM, CHARLTON K, SAYED R, DAUSAB M, MARCO C, RENDALL-MKOSI K and LONDON L (2000) The Dopstop Association - Promoting health on farms. Stellenbosch, 1998. Health Systems Trust Update 53 17-19. Health Systems Trust: Durban

TORRES L, BHORAT H, LEIBBRANT M and CASSIM F(2000) Poverty and the Labour Market. In: May J (ed.) Poverty and Inequality in South Africa: Meeting the Challenge. Chapter 4. David Phillip, Cape Town. 73-94.

WEAVER JMC (1993) A Preliminary Survey of Pesticide Levels in Groundwater from a Selected Area on Intensive Agriculture in the Western Cape. Report by the Division of Water Technology, CSIR. WRC Report No. 268/1/93. WRC, Pretoria. 